\title{
A Robotics Summer Camp for High School Students: Pipelines Activities Promoting Careers in Engineering Fields
}

\section{Dr. Mehmet Ayar, TUBITAK}

Dr. Mehmet C. Ayar is a scientific programs expert in the Scientific and Technological Research Council of Turkey (TUBITAK). He received his PhD. in Curriculum and Instruction with specialization in STEM education at Texas A\&M University in 2012. His research is in ethnographic studies of science and engineering practice, curriculum development, design of learning environments and robotics activities. He offers a graduate course in METU on communities of practice. Dr. Ayar worked for the Live Energy Project during his PhD studies at Texas A\&M University. Prior to his PhD studies, he worked for three years as a science teacher at a private school in Turkey.

\section{Dr. Bugrahan Yalvac, Texas A\&M University}

Bugrahan Yalvac is an associate professor of science education in the Department of Teaching, Learning, and Culture at Texas A\&M University, College Station. He received his Ph.D. in science education at the Pennsylvania State University in 2005. Prior to his current position, he worked as a learning scientist for the VaNTH Engineering Research Center at Northwestern University for three years. Yalvac's research is in STEM education, 21st century skills, and design and evaluation of learning environments informed by the How People Learn framework.

\section{Prof. Fatih Ugurdag, Ozyegin University}

Dr. H. Fatih Uğurdağ, a former veteran of Silicon Valley, received his PhD from Case Western Reserve University (CWRU) in Electrical Engineering \& Applied Physics in 1995. He received a BS in Electrical \& Electronics Engineering (EEE) as well as a BS in Physics from Bosporus University in 1986. He went to CWRU as a TA and did an MS thesis on machine vision (finished in 1989) and a PhD dissertation on parallel HW design. He worked in the industry in the USA non-stop between 1989-2004 at companies such as GE, GM, Lucent, Juniper, and Nvidia as a machine vision engineer, EDA software developer, and chip designer. Later (2005-2010) he was a faculty member at Bahçeşehir University in the EEE Dept. and then in Computer Engineering. He is also a consultant at Vestek Pixellence R\&D group of Vestel in ITU Technopark (since May 2007). Dr. Uğurdağ occasionally serves as an adjunct faculty member at Bosporus University and has ongoing funded research projects jointly conducted with Bosporus. His research interests span the areas of ASIC/SOC/FPGA design/automation, embedded systems, machine vision, educational software/web tools, and intelligent transportation systems.

\section{Dr. Alpaslan Sahin, Texas A\&M University}




\title{
A Robotics Summer Camp for High School Students: Pipelines Activities Promoting Careers in Engineering Fields
}

\begin{abstract}
In this paper we discuss the lived-experiences and the career interests of 27 high school students who participated in a two-week Robotics summer camp in 2012. The summer camp was designed by a team of engineering faculty, graduate students, and undergraduates. It provided the high school students with the opportunity to play and work with the materials to design a robot, build it, test it, and re-design it. A secondary purpose of the camp was to help students determine their career choice in the engineering fields. The participating 27 students were selected according to (a) their content questionnaire scores administered to 145 students in 34 different locations (b) personal interest essays, and (c) phone interviews. At the camp, the students took (a) a computer programming course, (b) a basic electronics course, and (c) proteus, pic, and microC training sessions. The students in pairs designed, built, tested, and modified their robots through practical implementations. They were given a variety of design challenges in each practical implementation. In the camp, invited researchers presented about their research and interest in Robotics and showed interdisciplinary perspectives of Robotics activities in the field (e.g., cardiovascular surgery). Also the students attended other extracurricular activities (e.g., a field trip to Ford Company). Study data were collected through interviews, field notes, and observations. The analysis of the qualitative data indicated that the camp increased the students' interest in engineering and helped them determine specific engineering fields that they wish to study in their academic career. Our observations revealed that the participating students engaged in activities with a community of engineers and gained first hand and original engineering design experience. We organized the study findings along with three dimensions: (a) Robotics summer camp as alternative to traditional learning environment in schools, (b) robotics activities as a means to nurture student interest in engineering fields and (c) robotics summer camp as venue for the students to determine specific engineering fields. Our study findings suggest offering outreach programs in practical engineering work to high school students.
\end{abstract}

\section{Introduction}

Education standards across many countries emphasize the interrelations among science, technology, engineering, and mathematics (STEM) ${ }^{1,2,3,4,5}$ and highlight the role of STEM education. Global reform movements aim to cultivate STEM education at K-16 levels because of the decreasing numbers of youth entering the STEM fields and medicine ${ }^{6}$ and the lack of student interest in these fields ${ }^{7}$. Encouraging the students to pursue careers in these fields is sine quo non for the countries to become the leaders in science, technology, military, media, and economy. Many interdisciplinary projects are designed and implemented in middle and high schools levels ${ }^{8}$, ${ }^{9}$ to encourage students to develop interest towards the STEM fields through different programs. For example, after school programs, various science clubs and summer camp programs are 
developed to have the students gain experience in interdisciplinary STEM fields. Students are provided with various activities to acquire competence ${ }^{10}$ and develop "system understanding" skills ${ }^{11}$.These programs play an important role in shifting the K-12 students' interests towards the STEM fields and allowing the students to determine their career choices before secondary education $^{12,13}$. In this paper, we describe the characteristics of a summer camp offered by a university in Turkey and investigate to what extent it attracts students' attention to interdisciplinary STEM fields and cultivate a career interest in engineering. The summer camp described in this study offered robotics activities. The students who participated in the camp were from different high schools in Turkey.

\section{Turkish Secondary and Higher Education}

Secondary education in Turkey is taken through a variety of high schools. Among these schools are science high schools, Anatolian high schools, technical high schools, Anatolian technical high schools, Anatolian teacher training high schools, vocational high schools, and social science high schools. In addition, there are many private secondary education schools and some international high schools and minority high schools ${ }^{14}$. Our study participants came from science high schools, Anatolian high schools, technical high schools, Anatolian high technical schools, minority high schools, and international high schools. These schools are conforming to educational standards, but they are eligible to develop their own curricula in regard to their students' needs and learning styles, and global educational standards.

High schools are typical, state schools where the students enter after their 8th grade. High school students are selected by a nation-wide exam. Students who cannot enter the Anatolian high school or Science High School often go to the typical state level schools.

Science high schools are for the students who are considerably good at science and mathematics subjects. Students are selected to enroll these schools through the nation-wide high school entrance exam. These students are expected to continue their higher education at the top universities in Turkey and elsewhere. Usually, the students of these schools go beyond the schooling objectives and they participate in national and international competitions in science, mathematics, engineering and other disciplines. Their teachers are also selected according to their content knowledge and the pedagogical content knowledge through various exams.

Anatolian high schools are considered an alternative to private high schools. These schools also accept students based on the nation-wide high school entrance exam. Students who enroll these schools take lower scores compared to those enrolled in science high schools. In addition, Anatolian technical and Technical high schools are for the students who want to learn schooling subjects as well as to gain technical skills. The students are selected to attend these schools through nation-wide high school entrance exam as well.

Private minority and international high schools are for the students who are considered minorities as well as who want to acquire a different education from the state and the private high 
schools. Minority schools work with the ministry of education, but they provide their students with the educational service to learn typical schooling subjects and their cultural rituals.

International high schools are distinct from minority schools in the sense that these schools host foreign students whose parents moved to Turkey for education, business, or so. These schools hire their teachers and administrators based upon their mission and vision.

Higher education is served by the state and private universities. As of year 2012, there are 168 universities in Turkey. 103 of them are state universities and 65 of them are private foundation universities. The main purpose of higher education is to equip the students with the knowledge, experience, and skills that will contribute to the country's development in economy, industry, science, and technology as well as to provide qualified man-power for the society ${ }^{15}$. However, a transition from the secondary education to the higher education occurs through nation-wide, central, competitive exams ${ }^{16}$. More than 1.5 million students each year from different high schools across the country take the same nationalized exam and compete with each other to enter a university and pursue their career in different fields. Some of them fail the exam and they retake it to enter a university in the following year. For instance, the recent research reports that 780.737 senior high school students applied for a national university exam in 2012. Other students who could not enroll any university program last years, those who did finish any program, and those who have already enrolled at universities, a total of 1.104 .742 individuals, reapplied for the 2012 exam. In 2012, around 1.8 million students took the exam, only 357.342 students were accepted university programs whereas 284.355 enrolled in two-year colleges ${ }^{17}$.

\section{Problem}

Engineering education has received little attention in the K-12 Turkish curriculum. Current Turkish education system aims to cultivate science, mathematics, and reading literacies through schooling activities. Schools, parents, and the stakeholders expect the K-12 students to succeed and enter the university after the 12 th grade. Students at the early ages began to develop interests and career objectives. They often want to be a doctor, an engineer, or a scientist. These careers are quite popular and appealing at the early ages in Turkey. However, many students are struggling to determine their career choice in the engineering fields although engineering is a preferred career choice among most students. Formal education system heavily emphasizes teaching the content knowledge in sciences and mathematics, yet it lacks the programs through which students engage in practical engineering work or in design activities utilizing most recent technology. In other words, the current education system in Turkey limits the students to master in sciences and mathematics and take the nation-wide exams to continue in post-secondary education. Private and university sponsored programs offer few opportunities for the students to do some hands-on and minds-on activities. A limited number of schools across the country encourage students to participate in extra-curricular activities (e.g., science fairs, clubs and Olympiads). These informal learning settings allow the students to spend time for practical work. Nevertheless, the K-12 students in Turkey are not sufficiently engaged in engineering activities or design challenges. 
We studied an informal learning setting in which two engineering professors, three graduate students, and four undergraduate students led the selected 27 high school students to complete some Robotics activities. In this setting, high school students played and worked with the materials and completed iterative design challenges to build a robot, test it, and re-design it. The participating students were asked to determine their career choice in the engineering fields. In our findings, we discuss the lived experiences, career interest in engineering, and the personal narratives of the students participated in the Robotics summer camp.

We posed three research questions to guide our investigation: (a) What were the characteristics of the Robotics summer camp? (b) How did the Robotics summer camp support students' attitudes towards and interests in the engineering fields? (c) How did the Robotics summer camp differ from the regular schooling activities?

\section{Theoretical Framework}

\section{Robotics}

Robotics has been a tool for various purposes in K-12 education ${ }^{11,18,19,20,21,22}{ }^{\text {. A learning }}$ environment ${ }^{23}$ supported with robotics activities allow the students to actively engage in design challenges and build and test concrete and mostly moving objects. Students learn by making tangible objects and construct their understanding ${ }^{24}$. Robotics activities are a means for students to consider career in the STEM fields ${ }^{25,26}$. These activities also provide individuals with the opportunity to utilize technology, and design and implement various concepts to understand the nature of interdisciplinary disciplines ${ }^{27}$. Therefore, robotics activities are very attractive and effective tools for students to sustain their interest in STEM fields.

\section{Outreach programs}

Outreach programs play an important role in attracting students' attention to and increasing their interest in various engineering fields. An outreach summer camp for high school students was developed by a group of engineering faculty ${ }^{28}$. The camp program included hands-on, competition-oriented projects in the electrical, environmental, mechanical, civil and chemical engineering fields. The main purpose of the summer camp was to expose the camp participants to acquire STEM subjects and to motivate them to continue their post-secondary education in engineering fields. Throughout the one-week camp, 30 students were engaged in projects associated with the real world problems such as air pollution, nanoparticles, desalination. Their study findings demonstrated that the offered activities were a means for students to develop critical thinking, teamwork, writing and leadership skills. As the students gained real-world experiences, they developed positive attitudes toward engineering fields.

Inspiring students to pursue STEM related careers at the early ages is crucial. Outreach programs for middle school students were designed by a group of researchers through the use of the LEGO MINDSTORM NXT robotics kits ${ }^{29}$. The outreach program consisted of lessons and competitive 
events through which students faced challenges. Students worked in teams of four to five to experiment with the LEGO kits and the programming. This program was served as a platform to engage the students in STEM related activities and help them develop interest in STEM programs at the college level.

A robotics outreach program was designed through the four-day LEGO courses ${ }^{27}$. These courses included the introduction of the LEGO kits, the LEGO programming, and the use of Robolab visual programming language. These courses were structured to enhance the students' motivation. The students were engaged in robot competitions. They were also introduced to a social robot and they interacted with it. Study findings indicated that students' learning experiences with the robotics activities helped improve students' motivation towards studying engineering.

The effects of Robotics activities on the students' performance associated with scientific process and creativity skills and students' perceptions about the interrelation between robots, human and society were investigated by a group of educators ${ }^{18}$. The Robotics activities were utilized through the LEGO Mindstorms NXT 2.0 for 23 students at the ages of 12-13. The participating students were engaged in a process allowing them to recognize a robot and its parts, work with sensors, understand a basic programming and use a robot to find solutions for some socio-scientific issues. Study findings indicated that Robotics is viewed as a means for the students to learn science topics and develop problem solving skills, which in turn can bolster their interest in STEM fields.

In sum, most robotics activities aim to draw students' attention to the engineering fields, motivate them to pursue engineering in the college level and study interdisciplinary concepts. Similarly, we studied an outreach program offered at a private university to energize the students' interest in engineering fields and stimulate them to determine engineering as a career choice. Because they had already had experience with science and engineering activities through science fairs, extracurricular clubs, they might have interested in engineering, yet it was not clear if they have chosen engineering as a career option. The Robotics summer camp we studied was very different from the activities students often engage in Turkey. There are some programs to introduce the culture and environment at the university level to the K-12 students. In those programs, students often visit the university campus and learn about the engineering program through lectures and workshops. The outreach program we describe in this paper actively engaged the students in engineering design challenges and provided the first-hand experience in engineering work. In addition, the program was different from those in the literature because the participating students utilized actual mechanicals and electronic tools other than using LEGO kits. 


\section{Study Context}

The Robotics summer camp studied in this paper was organized by a team of engineering faculty and university students. It was designed for high school students. Students were invited to participate in the camp a year in advance. Two requirements were set for participation. Students completed a content questionnaire and wrote a personal essay why they were interested in participating in the robotics camp. Students who completed two requirements were interviewed. 27 out of 131 applied students were selected to participate at the Robotics Summer Camp. 27 students were grouped in pairs. This grouping was made by the team leader of the organization because some students were from the same school, and the organization team itself wanted the groups to mingle with different individuals. The team leader expected them to work in a collaborative manner. Only two students worked individually. Senior undergraduate and graduate students (we call mentors) were assigned to student groups, yet all students were told that mentors would help anyone in the project upon their request.

The 12 days RoboCamp program (Table 1) included invited lectures by the engineering researchers and faculty members. For example, a faculty presented about his doctoral study where he had designed a robot that can be used in cardiovascular surgery. Another presentation was about designing and making a robot that mimics humans. The camp provided the participating students with theoretical background through (a) a computer programming course (6hrs), (b) a basic electric-electronic course (4hrs.), (c) Proteus/PIC/MicroC training course (5hrs.), and (d) Electronics applications (Printed Circuit Boards and its production and Knight Rider on Board) (4hrs.). While the programming course was taught by a faculty, other courses were taught by a graduate student. The faculty members were in secondary role. In other words, the faculty members stepped in when they realized any missing point during the lectures. After the students learn about the theoretical background, they were engaged in practical works (e.g., brazing things on a printed circuit board) to begin making their own robot. The students were given some experiments to transfer a circuit to breadboard; to transfer a circuit to breadboard through LED; and to test CNY70 sensor on the breadboard. They also studied DC motor, 7895 regulator, PIC 16F628A (Micro Controller), L298 integration and LM 324 (updated).

As an extracurricular activity, the students visited the Ford Company where passenger cars and other vehicles were manufactured and exported to our countries. In their trip to the Ford Company, students have seen where and how the robots are used for automobile production. At the same time, they witnessed the environment where the engineers work after higher education.

The camp participants were encouraged to attend the presentations of visiting faculty and graduate students at different institutions. Through these presentations the participants listened to the narratives of the faculty on how they become engineering researchers. The visiting graduate students shared their experience in engineering with the participants and talked about where they were at the moment and where they want to go as the next step. Introducing the visiting faculty 
and the graduate students to the camp participants was essential to help students envision their near future if they choose engineering as their career option.

The students were encouraged to design, build, test, and modify their robots through practical implementations. They were informed daily what and where they would do practical works to see if their robot works as expected. They were given a challenge, which was to make a robot on race course 1 (Figure 1). If they pass the challenge on the course 1, two more challenges are given them to pass on the course 2 (Figure 2) and course 3 (Figure 3) subsequently. If they do not fail in these challenges, they are expected to compete on the course 4 (Figure 4). It is the final race for them to win and get scholarship to continue their higher education.

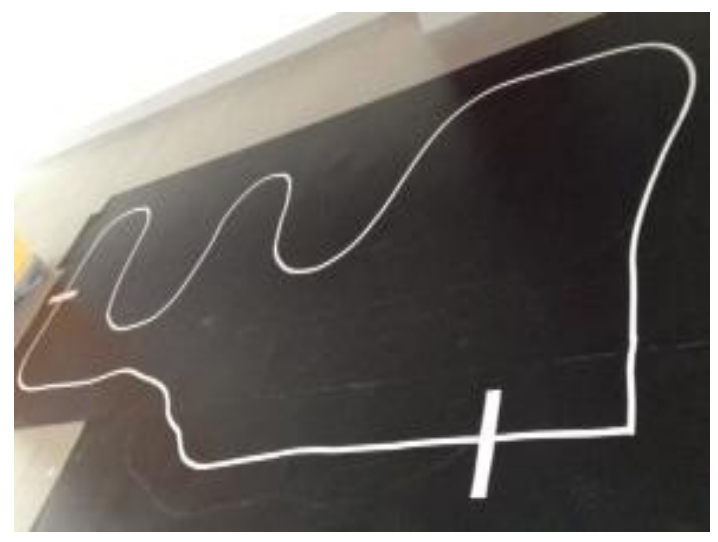

Figure 1

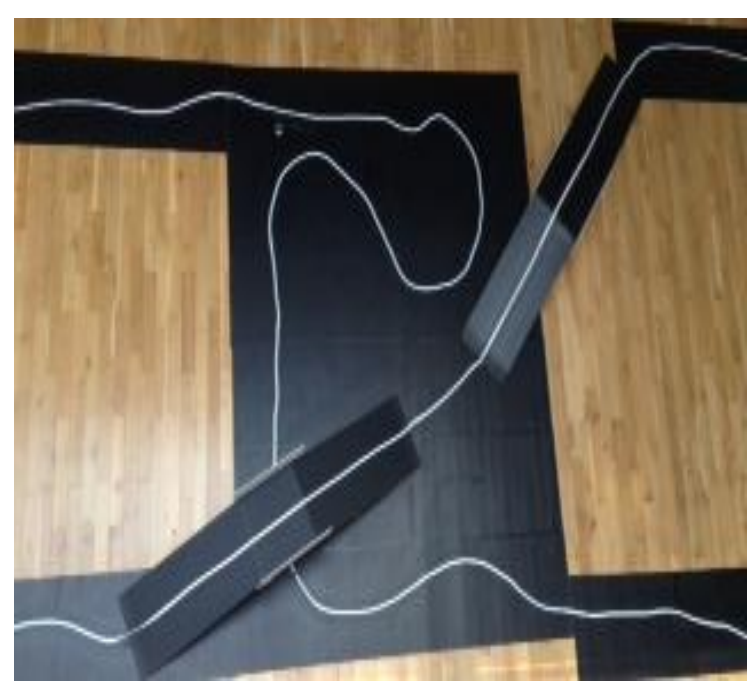

Figure 3

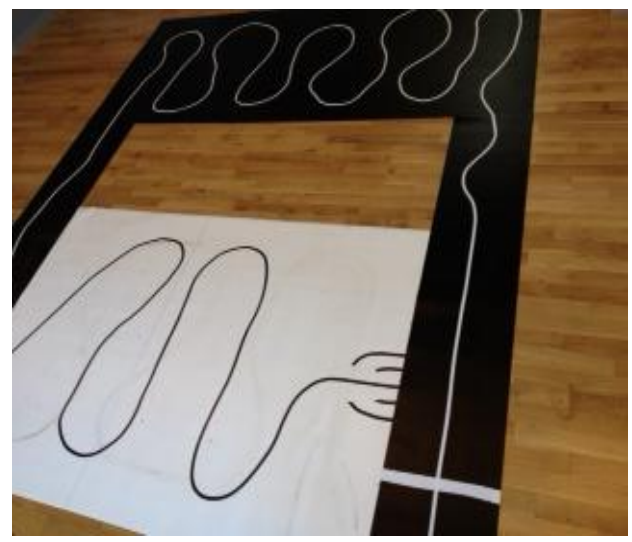

Figure 2

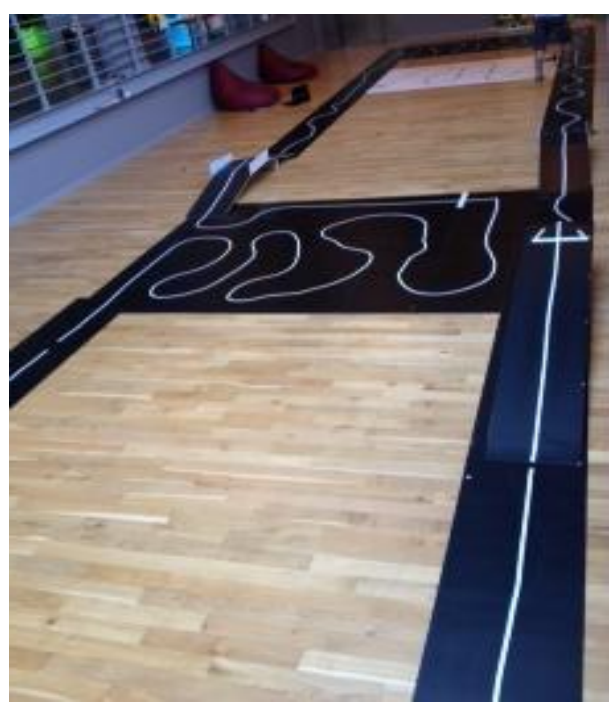

Figure 4 
Table 1 The Robotics Summer Camp Program

\begin{tabular}{|c|c|c|c|c|c|c|c|c|c|c|c|c|c|c|c|}
\hline & 9:00-9:10 & 9:10-9:25 & $9: 25-9: 45$ & 9:45-10:45 & $10: 45-12: 00$ & 12:00-12:30 & \begin{tabular}{|l|}
$12: 30-$ \\
$13: 30$ \\
\end{tabular} & \multicolumn{2}{|c|}{$13: 30-14: 30$} & \multicolumn{2}{|c|}{$14: 30-15: 15$} & \multicolumn{2}{|c|}{$15: 15-18: 30$} & $\begin{array}{l}18: 30- \\
19: 30\end{array}$ & 19:30-21:00 \\
\hline$\vec{\theta}-$ & $\begin{array}{l}\text { Dean's } \\
\text { Speech }\end{array}$ & $\begin{array}{c}\text { Team } \\
\text { Leader's } \\
\text { Speech }\end{array}$ & $\begin{array}{c}\text { Student } \\
\text { Orientation }\end{array}$ & \begin{tabular}{|c} 
Robotics \\
and NAO \\
Robots \\
Presentation \\
\end{tabular} & $\begin{array}{l}\text { A Faculty's } \\
\text { Presentation }\end{array}$ & Ice Breaker & Lunch & \multicolumn{2}{|c|}{$\begin{array}{l}\text { A Faculty's } \\
\text { Presentation }\end{array}$} & \multicolumn{2}{|c|}{$\begin{array}{l}\text { Robot } \\
\text { Demos }\end{array}$} & \multicolumn{2}{|c|}{ Programming } & Dinner & \\
\hline Eี $N$ & \multicolumn{6}{|c|}{ Programming } & Lunch & $\begin{array}{l}\text { A Fac } \\
\text { Presel }\end{array}$ & $\begin{array}{l}\text { ulty's } \\
\text { tation }\end{array}$ & \multicolumn{4}{|c|}{ Basic Electronic Education } & Dinner & \\
\hline Eे & \multicolumn{6}{|c|}{ Proteus/PIC/MicroC Education } & Lunch & \multicolumn{4}{|c|}{ Proteus/PIC/MicroC Education } & \multirow{2}{*}{\multicolumn{2}{|c|}{\begin{tabular}{c|} 
A Faculty's \\
presentation \\
Begin Making a Robot: \\
Brazing Things on \\
Board \\
\end{tabular}}} & Dinner & \\
\hline हैं & & & nted Circuit E & Board and its I & Production & & Lunch & $\begin{array}{r}\text { Knight } \\
\text { Printed Cit }\end{array}$ & $\begin{array}{l}\text { Rider on } \\
\text { cuit Board }\end{array}$ & $\begin{array}{l}\text { A Facu } \\
\text { Present }\end{array}$ & $\begin{array}{l}\text { llty's } \\
\text { ation }\end{array}$ & & & Dinner & Free Study \\
\hline$\vec{E}$ in & \multicolumn{6}{|c|}{ A Faculty's presentation } & Lunch & \multicolumn{6}{|c|}{ Make a Robot } & Dinner & \\
\hline $\overrightarrow{\mathrm{A}}$ & \multicolumn{7}{|c|}{ Trip to Ford Company } & \multicolumn{6}{|c|}{ City Sightseeing-Istanbul } & Dinner & \\
\hline อิ & \multicolumn{6}{|c|}{ Practice in Race Course 1 (Short) } & Lunch & \multicolumn{6}{|c|}{ Practice in Race Course 1 (Short) } & Dinner & $\begin{array}{c}\text { Race in Race } \\
\text { Course } 1\end{array}$ \\
\hline تี $\infty$ & \multicolumn{5}{|c|}{$\begin{array}{l}\text { Practice in Race Course } 2 \text { (Long) } \\
\text { (Tricks and Details) }\end{array}$} & $\begin{array}{l}\text { A Faculty's } \\
\text { Presentation }\end{array}$ & Lunch & \multicolumn{6}{|c|}{ Practice in Race Course 2 (Long) } & Dinner & \\
\hline हैं & \multicolumn{6}{|c|}{ Practice in Race Course 2 (Long) } & Lunch & \multicolumn{6}{|c|}{ Competition in Race Course 2 (Long) } & Dinner & \\
\hline 르을 & \multicolumn{6}{|c|}{ Practice in Race Course 3} & Lunch & \multicolumn{6}{|c|}{ Competition in Race Course 3} & Dinner & \\
\hline है & \multicolumn{6}{|c|}{ Practice in Race Course 4 (Final Version) } & Lunch & \multicolumn{6}{|c|}{ Practice in Race Course 4 (Final Version) } & Dinner & $\begin{array}{c}\text { Practice in } \\
\text { Race Course } 4 \\
\text { (Final Version) } \\
\end{array}$ \\
\hline Ẽ & \multicolumn{6}{|c|}{ Practice in Race Course 4 (Final Version) } & Lunch & Final Race & $\begin{array}{l}\text { Dean's } \\
\text { speech }\end{array}$ & $\begin{array}{l}\text { Vision } \\
\text { speech }\end{array}$ & $\begin{array}{r}\text { Ford } \\
\text { Repre } \\
\mathrm{S}\end{array}$ & $\begin{array}{l}\text { Company } \\
\text { esentatives' } \\
\text { Speech }\end{array}$ & $\begin{array}{l}\text { A Faculty } \\
\text { in Japan } \\
\text { Speech }\end{array}$ & $\begin{array}{l}\text { Winners } \\
\text { Ceremony }\end{array}$ & \\
\hline
\end{tabular}




\section{Study Methods}

In this qualitative study, we collected data through interviews, field notes, and observations. We interviewed 24 students in pairs and three students individually. We took field notes when the students were taught theoretical background, engaged in practical work to make their own robot, and compete with each other to win the final race. Field notes were taken when invited speakers talked about their research interests. We observed the students as they worked at the electricelectronic laboratory and they tested their robot models on the race courses. We identified student-student, student-faculty, and student-mentor interactions. These observations were a means for us to observe the iterative processes through which robot models were developed.

We transcribed the interviews verbatim and analyzed them using the constant-comparative method $^{30}$. We triangulated the findings from interviews with the field notes and observations.

\section{Study Participants}

The study participants were twelve students in the 11th grade and 15 students in 12th grade from the different high schools across Turkey. Overall there were 27 students in the camp, 23 of whom were male and four were female. Thirteen out of 27 participants came from Anatolian High Schools. One participant was from an Anatolian Technical High School and another was from a Technical High School. Eight participants were from Science High Schools; three participants were from High schools. Only one participant was from an International High School. Four out of 27 participants came from private high schools. The remaining was from the state high schools. One out of 27 participants was from a minority school (Table 2).

Table 2. Participants' schools, school types, grade levels and sex (All participant names are pseudonym)

\begin{tabular}{|c|c|c|c|c|c|}
\hline No & $\begin{array}{c}\text { Participant } \\
\text { Name }\end{array}$ & $\begin{array}{c}\text { School } \\
\text { Classification }\end{array}$ & $\begin{array}{c}\text { School } \\
\text { Type }\end{array}$ & $\begin{array}{r}\text { Grade } \\
\text { Level }\end{array}$ & Sex \\
\hline 1 & Baris & Anatolian High School & Public & 11 & M \\
\hline 2 & Kadir & Anatolian Technical High School & Public & 11 & M \\
\hline 3 & Cagatay & Anatolian High School & Public & 12 & M \\
\hline 4 & Elif & Anatolian High School & Public & 12 & $\mathrm{~F}$ \\
\hline 5 & Serkan & Science High School & Public & 11 & M \\
\hline 6 & Erdogan & Science High School & Public & 11 & M \\
\hline 7 & Ata Ali & Anatolian High School & Public & 11 & M \\
\hline 8 & Hasan & Anatolian High School & Public & 12 & $\mathrm{M}$ \\
\hline 9 & Hakan & Anatolian High School & Public & 11 & M \\
\hline 10 & Husrev & Science High School & Public & 12 & $\mathrm{M}$ \\
\hline 11 & Abdulkadir & Anatolian High School & Public & 12 & $\mathrm{M}$ \\
\hline 12 & Kaan & Anatolian High School & Public & 12 & $\mathrm{M}$ \\
\hline 13 & Mahmut & Anatolian High School & Public & 11 & $\mathrm{M}$ \\
\hline 14 & Yakup & Science High School & Private & 11 & M \\
\hline 15 & Simon & High School & Minority-Private & 12 & $\mathrm{M}$ \\
\hline 16 & Serhan & Science High School & Public & 12 & $\mathrm{M}$ \\
\hline
\end{tabular}




\begin{tabular}{lcclll}
\hline 17 & Naz & International High School & Private & 11 & F \\
18 & Batuhan & Anatolian High School & Public & 12 & M \\
19 & Omer & Anatolian High School & Public & 12 & M \\
20 & Ahmet & Science High School & Public & 11 & M \\
21 & Onur & High School & Private & 12 & M \\
22 & Mert & Anatolian High School & Public & 11 & M \\
23 & Busra & Science High School & Public & 12 & F \\
24 & Cisem & Anatolian High School & Public & 11 & F \\
25 & Tacettin & High School & Public & 12 & M \\
26 & Yigit & Science High School & Public & 12 & M \\
27 & Anil & Technical High School & Public & 12 & M \\
\hline
\end{tabular}

\section{Findings}

We organized the study findings along with three dimensions: (a) Robotics summer camp as alternative to the traditional learning environment in schools, (b) robotics activities as a means to nurture student interest in engineering fields, and (c) robotics summer camp as venue for the students to choose their future career options.

\section{Robotics summer camp as alternative to the traditional learning environment in schools}

Our study findings indicate that in the traditional learning environment, our participants mostly learned about the content knowledge. They were motivated to learn science, mathematics and other subjects to succeed in the nation-wide university entrance exam. Although most of the camp participants attended Science High Schools and Anatolian High Schools where the handson and minds-on activities were mostly offered and students were encouraged to work at science laboratories, they were usually directed to get familiar with exam questions and techniques. Their teacher and school administrator played an important role in directing them to study for the exam. The higher the score they get the better the chance they will have to enroll at a university of their choice. Meantime, their high school will receive credit because of their achievement in the exam. In that regard, the students stated in their interview;

Erdogan: Let me talk about the physics course. Our teacher is well-educated and an expert in her field, but I guess because of our education system, we have a lot of things to learn, we have to go over the concepts asked in the university entrance exam and solve a lot of exam questions before that exam in our classroom.

Elif: I think our school is different from other Anatolian High Schools in the sense that we are not taught chemistry or physics in the classroom. Before the exam, we collect course notes and work on them. In addition to this, we are less taken to the laboratory for doing experiment. However, we are usually encouraged to do some projects such designing and making a car outside the classroom.

Serkan: As a student in a Science High School, we are already exposed to many courses different from the other high schools. We are not using any specific textbook, but our 
teacher compiles many documents to teach the chemical concepts, and she encourages us to solve extra problems. This is how we get ready for the exam.

Hakan: We usually learn physics and chemistry concepts from the textbooks or from what our teachers taught us. We go to the laboratory, but we do simple things that are in the textbooks. In other words, the science activities provided to us are limited to the content of textbooks. I would criticize our education system here because when you take the university entrance exam, you are expected to solve a question in a minute and that determines your future. I am not sure how this system helps me in my life

Hasan: I think that the textbooks are problematic. For instance, when you open the physics textbooks, you see lots of information and there are many things to cover. In addition, you have to face with many formulas to memorize and learn. These are all about the education system based upon memorization. I do not think it is nice for the formal education.

Busra: In my school [Science High School], our teachers are well enough to teach science and mathematics concepts. I view our school as dershane (tutoring center) because our teachers prepare worksheets and exams. Each teacher has their own source book to use in the class. Therefore, we use these books that provide example questions for the university entrance exam. Sometimes music and art courses are replaced with mathematics and science courses to provide us with problem-solving sessions. Using laboratory to do experiment is very limited because our school is exam-centered.

Robotics summer camp was alternative to their classroom environment because the students were provided with the opportunity to perform hands-on and minds-on activities as they designed their robot model, test it, re-design it and retest it. This iterative process engaged them to think critically and analytically and find the best solution to deal with challenges given by the organization team. Some camp participants stated in their interviews:

Anıl: We tried to find the best gravitational center and decided which sensor distance would be best for our robot model. [In that regard], we asked many questions to ourselves to find the solution. In addition, we thought where to put batteries and motor on the robot model. We questioned what happens if we put wheeled motors under the model, we tested it and observed that it did not work. Then we changed its place.

Erdogan: We have to design a robot and make it working on the race course 1 [Figure 1]. According to the given challenge, we have to determine the number of sensors and angle degree that will allow our robot to trace on the race course 1 . Otherwise, we will be punished with extra seconds during the competition. We tested our robot on the course 1, if the robot turned on the curve earlier; we tried to find the problem and questioned why this happened.

It was an alternative to their conventional learning environment because they worked in pairs, requested help from their mentors and engineering faculty members when they met a problem or they could not find a solution to the challenge. Less knowledge authority or power between the camp participants and the organization team members encouraged them to collaborate and develop mutual interactions to make a progress in the iterative design process. Learning environment offering flexibility and collaboration in the camp program played a triggering role in establishing camaraderie among the camp participants because they worked in pairs, spent their 
days and nights to make their robot to participate the final race for scholarship and shared their experience and competence to solve the challenges given in the camp program. This is the contrary to the learning environment in their schools where individual learning is supported and competition among the students is inevitable. They mentioned in their interview:

Erdogan: In this camp, as we tried to make our robot, we worked together with my partner, Ata Ali. We tried to find a solution for the challenge to make our robot working through many trials. During this process, there were many things that I did myself, but my programming skill was limited. At this point Ata Ali helped me out and contributed to the process. I think that working with my partner and mentors was essential for us to complete our robot to participate in the final race.

Serkan: I did not see any competition among the groups. When one group passes the challenge, then it is shared with the other groups what they have done and which method they have used to do so. I think I have a good relation with my partner and the organization team members. I worked with my partner over night to solve the challenges as friends. Meantime, the atmosphere at the camp was warm enough to develop friendship with other participants and even with undergraduate students.

Elif: I did not see such competition either. Instead, we developed friendship although we came from different school at different locations across the country. We talked about ourselves, our schools and our future plans after high school.

\section{Robotics activities as a means to nurture student interest in engineering fields}

It has been clear to us that the camp participants were selected to participate in the Robotics summer camp because they were very interested in engineering fields. At the same time we were aware that their schools do not offer any Robotics activity. Students' parents might have supported them to develop interest towards engineering and simply because they were in the camp, they had some interest in engineering. However, we do not consider their limited interest and family support enough to nurture a career interest in engineering. The summer camp activities nurtured their interest in engineering fields more substantially for three reasons. First, schooling activities are only limited to teaching science and mathematics content knowledge. The students at schools (as mentioned above) are exposed to memorizing knowledge, use that knowledge to succeed in the university entrance exam and if interested, pursue engineering as career due to the perception of engineering in the society. However, the camp participants were exposed to the Robotics activities through which they had a chance to work with peers, mentors and faculty, recognize and use mechanical, electronic and electrical materials (e.g., LED, sensor, capacitor, breadboard, AC, DC circuits, DC motor and PIC), and programming to make a robot. These activities were a means to nurture their interest in engineering field other than sparking their interest as we have seen through guidance service at schools. Some participants stated in their interviews:

An1l: I am very interested in Robotics and that's why I wanted to participate in this camp. Before this camp, I already made a robot tracing the line and had programming experience. At this camp additionally I learned using MicroC pro and met a microprocessor like 16M628A. I learned different perspectives to design a robot and make it working. All of which encouraged me to continue to work on Robotics. 
Elif: We learn background of electronics in schools, like we design electric circuit on the paper, but you cannot associate it with electronic engineering. Herein Robotics activities we were engaged in contributed to my passion to engineering. At the beginning, I was not sure to pursue electric engineering, but after these Robotics activities I am sure I will.

Second, Robotics activities were joyful, motivating, encouraging, and interdisciplinary to nurture their interest in engineering. Because the camp participants were allowed to play with the given materials to design a robot, test it, re-design it and re-test it, they felt motivated to pursue engineering as career. In contrary, at their schools they were only given activities limited to theoretical background knowledge about the relevant topic. There was no space for them to apply theory into practice through schooling activities. In addition, through Robotics activities, they realized that they used physics, engineering design and programming concepts to make a robot. This enabled them to understand the interdisciplinary nature of Robotics. Therefore, Robotics activities were joyful, encouraging and interdisciplinary that would nurture their interest in engineering fields. Some participants stated in the interviews:

An1l: To make our robot working we worked until the morning last night because there was a problem on the system. We did the first protype using microprocessors and different motors and tested it and it worked well. It was pretty joyful for us and we were happy. The day after, we shared it with the other groups and they used our solution for their robots. Therefore, we solved the problem.

Erdogan: I did not understand how fast this program ended. I liked it very much because we worked at the laboratory during the day and the night. This program enabled us to learn something about electric and electronic engineering. We learned how to solve a problem through programming and testing and redesigning our robot model. I wished this program could be more than 12 days. Really I cannot get enough of this program.

Ata Ali: This program was awesome and I cannot believe how fast it ended. I wished it could be longer. I believe that I learned the nature of engineering work [designing a robot]. I have realized that we used physics content knowledge. We have to think in-depth and question the circumstances [how the robot will pass the curve]. These were motivating. When go back to my home, I will continue to work even though my mother does not allow me at home.

Third, Robotics activities were a means for the camp participants to make their dreams come true because they were exposed to hands-on, minds-on and problem solving activities at the summer camp. They were encouraged to develop their own strategies to make a robot working. However, it was not possible to observe such opportunity in their school because the education system wants them to learn specific learning content standards and do not provide them with the opportunity to pursue their own ideas and take the ownership of their learning. Therefore, Robotics activities were the opportunity for them to do what they envision to do throughout the camp program although they were expected to pass all the challenges to participate in the final race. They were all aware of this reality, but winning or losing the final race was not criterion for them because they have been engaged in doing engineering work. Some participants stated in their interview: 
Çisem: Playing with circuits is awesome. Make yourself familiar with the materials given to you and tell yourself, this is what you did and this is the thing that you made working.

Abdulkadir: If we were thought these activities through textbooks, I would not learn that much. I cannot imagine concepts given in textbook because they are not practical.

Busra: People learn by doing. By listening things you keep in your mind, but as long as you do not do in practice, you cannot learn. Here we did learn that learning occurs when you are engaged in practical work. I think that people can be happy when they are actively engaged in activities.

\section{Robotics summer camp as venue for the students to choose their future career options}

Robotics summer camp was a platform where the camp participants and the organization team members developed a common goal to pursue when the camp participants select the engineering as their career at the university. Throughout the camp program, many engineering faculty members were introduced to the camp participants in addition to the Robotics activities. These members presented and talked about their research interest in engineering fields and shared their engineering education stories with them. Some visiting graduate students in the engineering fields were invited to talk about their experience in electric-electronic and mechanical engineering fields, with whom they worked and they are still working and opportunities in engineering fields in Turkey and other countries (e.g., US). The presentations of the faculty and graduate students helped the camp participants understand what's going on in the engineering fields, determine what they can do if they choose engineering field as their career, and be aware of the interdisciplinary aspects in the engineering field. In addition, the camp participants interacted with their mentors and the faculty members during the coffee breaks, lunch and dinner to talk about themselves, their interest and experience with engineering activities. Thus, these informal conversations and formal presentations were the essential elements of the Robotics summer camp to help the students determine the specific engineering fields as they were about to enter university and choose engineering as their career throughout higher education. Some participants stated in their interviews:

Hasan: [Faculty] presentations were appealing for career choice because these presentations were very informative and beneficial. I was thinking of whether to choose electric-electrical engineering or mechanical engineering. Through these presentations I realized how different electric-electronic engineering was, how it overlaps with other disciplines. Then I made my decision, [electric-electronic engineering].

Hakan: I want to be a mechanical engineer. People talk about what a mechanical engineer does...makes machines....make motors...Through the presentations, we looked this field from a boarder perspective... what more mechanical engineers do...

Anıl: I will choose electric-electronic engineering as career and then I will pursue master's degree in Robotics. At this point, a faculty's presentation about medical robots was very contributing to make my decision on Robotics. Other faculty members talked about their research interest in engineering fields and projects in Turkey and world as well. 
Kaan: I talked to a faculty here about making double major [mechanical and electricelectronic engineering] in the future. I like mechanical engineering, but you also need electric-electronic knowledge. Mechanical engineering is my interest area, in other words, I like producing, and I like designing, additional electric-electronic knowledge should be learned. Therefore, I want both [mechanical and electric-electronic engineering].

Husrev: Presentations are very informative to understand the borders of engineering fields. However, I was already interested in engineering. What I have seen here allowed me to conceptualize what engineering really is. What have been done and searched in engineering fields was very informative for me. This encouraged me to choose this field certainly.

Abdulkadir: Apparently, I am the one who wants to become an electric-electronic engineer from the beginning. The presentations made in the camp program were very encouraging. I used to know electric-electronic engineering with electric circuits and schemas. However, we can see this engineering field in biology, medicine. These presentations enhanced my understanding of engineering.

\section{Conclusion}

This study indicates that the Robotics summer camp was critical for the high school students to learn about the Robotics and exchange their knowledge, experience, and competence to develop, test, and re-design a robot. This opportunity allowed them to work in collaboration. They learned from each other in their design activities. The experiences students received in the robotics summer camp were a means to conceptualize the real engineering work and how the engineers work in their positions. In addition, they realized that the nature of engineering work contains problems and solutions to generate and use. The camp also served as a platform for the students, who are about to enter the university, to determine their career choices in the engineering fields.

The Robotics summer camp was competition-centered in theory, but in practice it was not. We think that competition itself was a tool that provided the participants with excitement. The competitive atmosphere did not stop the paired students to ask questions to each other. Working in pairs or in collaboration with mentors and other groups were a means that allowed them to feel part of a group as whole and contributed to a feeling of collaborative learning.

\section{Bibliography}

1. Department of Education. (2010). ESEA blueprint for reform: The reauthorization of the elementary and secondary education act. Washington, DC: Author. Retrieved from http://www2.ed.gov/policy/elsec/leg/blueprint/blueprint.pdf

2. National Science Board. (2010). Preparing the next generation of STEM innovators: Identifying and developing our nation's human capital. Arlington, VA: The National Science Foundation. 
3. President's Council of Advisors on Science and Technology. (2010). Prepare and inspire: K-11 education in science, technology, engineering, and math (STEM) for America's future. Retrieved from http://www.whitehouse.gov/sites/default/files/microsites/ostp/pcast-stemed-report.pdf

4. Commission of the European Communities. (2008). Report of the commission of the European communities on progress towards the Lisbon objectives in education and training. Retrieved from http://ec.europa.eu/education/lifelong-learning-policy/doc/report08/report_en.pdf

5. Commission of the European Communities. (2010). Report of the commission of the European communities on Lisbon strategy evaluation. Retrieved from http://ec.europa.eu/archives/growthandjobs_2009/pdf/lisbon_strategy_evaluation_en.pdf

6. Ewers, T.G. (2010). Idaho robotics opportunities for K-11 students: A K-11 pipeline activities promoting careers in science, engineering and technology. 48(1). http://www.joe.org/joe/2010february/iw2.php

7. Cavas, B., Cakiroglu, J., Ertepinar, H., \& Cavas, P. (2010).Explaining some factors on Career Choices in Teaching Science, Technology and Mathematics. 3rd World Conference on Science and Technology Education, Proceedings of 3rd ICASE World Conference, 37-39, Tartu, Estonia.

8. Cunningham, C.M, Knight, M.T., Carlsen, W.S, \& Kelly, G. (2007). Integrating engineering in middle and high school classrooms. International Journal of Engineering Education, 23(1), 3-8.

9. Wendell, K., Connoly, K., Wright, C., Jarvin, L., Rogers, C., Barnett, M., \& Marulcu, I. (2010, October).Incorporating engineering design into elementary school science curricula. Paper presented at the Annual Meeting of American Society for Engineering Education. Singapore.

10. Gallego, M. A., \& Finkelstein, N. D. (2005). When the classroom isn't in school: The construction of scientific knowledge in an after-school setting. In R.Y. Yerrick, \& W-M. Roth (Eds.), Establishing scientific classroom discourse communities: Multiple voices of teaching and learning research (pp.293-313). Mahwah; NJ: Erlbaum.

11. Sullivan, F. R. (2008). Robotics and science literacy: Thinking skills, science process skills and systems understanding. Journal of Research in Science Teaching, 45,373-394.

12. Bruder, S., \& Wedeward (2003, September). An outreach program to integrate Robotics into secondary education. IEEE Robotics \& Automation Magazine, pp. 25-29.

13. Kolberg, E., \& Orlev, N. (2001). Robotics learning as a tool for integrating science technology curriculum in K-12 schools. 31th Annual Frontiers in Education Conference. Impact on Engineering and Science Education Conference Proceedings, Reno, NV, USA.

14. OECD (2005). Review of educational policies for education: Turkey. Paris: OECD:

15. OECD (2007). Reviews of national policies for education-Basic education in Turkey. Paris: OECD.

16. Ayas, A. (2012). An examination of Turkish science curricula from a historical perspective with an emphasis on learning outcomes. In S. Bernholt, K. Neumann, \& P. Nentwig (Eds.), Making it tangible: Learning outcomes in science education, pp. 399-424, Waxmann. Münster.

17. OSYM (2009). 2012 OSYS yerlestirme sonuçlarına ilişkin sayısal bilgiler. Retrieved from http://dokuman.osym.gov.tr/pdfdokuman/2012/OSYS/Yerlestirme/2012YerlestirmeSayisalBilgileri.pdf

18. Cavas, B., Kesercioglu, T., Holbrook, J., Rannikmae, M., Ozdogru, E., \& Gokler, F. (2012, April). The effects of Robotics club on the students' performance on science process and scientific creativity skills and perceptions on robots, human and society. Proceedings of 3rd International Workshop Teaching Robotics, Teaching with Robotics Integrating Robotics in school Curriculum Riva del Garda (Trento, Italy), pp. 4050.

19. Chambers, J. M., Carbonaro, M., Murray, H. (2008). Developing conceptual understanding of mechanical advantage through the use of Lego robotic technology. Australasian Journal of Educational Technology, 24(4), 387-401.

20. Chambers, J.M., Carbonaro, M. (2003). Designing, developing, and implementing a course on Lego robotics for technology teacher education. Journal of Technology and Teacher Education, 11, 209-241.

21. Wagner, S.P. (1998). Robotics and children: Science achievement and problem solving. Journal of Computing in Childhood Education, 9, 149-165.

22. Weinberg, J.B., White, W.W., Karacal, C., Engel, G., \& Hu, A.P. (2005). Multidisciplinary teamwork in a robotics course. ACMSIGCSE Bulletin, 37, 446-450.

23. Weinberg, J. B. \& Yu, X. (2003, June). Robotics in education: Low-cost platforms for teaching integrated systems. IEEE Robotics \& Automation Magazine. 10(2), 4-6.

24. Papert, S. \& Harel, I. (1991). Situating constructionism: Constructionism. Ablex Publishing Corporation. 
25. Kauffmann, P., Hall, C., Batts, D., Bosse, M., \& Moses, L. (2009). Factors influencing high-school students' career considerations in stem fields. In Proceedings of the 2009 ASEE Annual Conference and Exposition.

26. Ruiz-del-Solar, J. (2010). Robotics-centered outreach activities: An integrated approach. IEEE Transactions on Education, 53(1), 38-44.

27. Weinberg, J.B., Engel, G.L., Gu, K., Karacal, C.S., Smith, S.R., White, W.W., \& Yu, X.W. (2001). A multidisciplinary model for using robotics in engineering education. Proceedings of the 2001 American Society for Engineering Education Annual Conference \& Exposition, City.

28. Yilmaz, M., Ren, J., Custer, S., \& Coleman, J. (2010). Hands-on summer camp to attract K-12 students to engineering fields. IEEE Transactions on Education, 53(1), 144-150.

29. Salamon, A., Kupersmith, S., Housten, D. (). Inspiring future young engineers through Robotics outreach. Retrieved from http://www.atl.lmco.com/papers/1559.pdf

30. Glaser, B. G., \& Strauss, A. M. (1967). The discovery of grounded theory: Strategies for qualitative research. Chicago: Aldine. 